\title{
Identification of the full set of Listeria monocytogenes penicillin-binding proteins and characterization of PBPD2 (Lmo2812)
}

Dorota Korsak ${ }^{1 *}$, Zdzislaw Markiewicz ${ }^{1}$, Gabriel O Gutkind², Juan A Ayala ${ }^{3}$

\begin{abstract}
Background: Bacterial penicillin-binding proteins (PBPs) can be visualized by their ability to bind radiolabeled or fluorescent $\beta$-lactam derivatives both whole cells and membrane/cell enriched fractions. Analysis of the Listeria monocytogenes genome sequence predicted ten genes coding for putative PBPs, but not all of their products have been detected in studies using radiolabeled antibiotics, thus hindering their characterization. Here we report the positive identification of the full set of $L$. monocytogenes PBPs and the characteristics of the hitherto undescribed PBPD2 (Lmo2812).

Results: Eight L. monocytogenes PBPs were identified by the binding of fluorescent $\beta$-lactam antibiotic derivatives Boc-FL, Boc-650 and Amp-Alexa430 to proteins in whole cells or membrane/cell wall extracts. The gene encoding a ninth PBP (Lmo2812) was cloned and expressed in Escherichia coli as a His-tagged protein. The affinity purified recombinant protein had DD-carboxypeptidase activity and preferentially degraded low-molecular-weight substrates. L. monocytogenes mutants lacking the functional Lmo2812 enzyme were constructed and, compared to the wild-type, the cells were longer and slightly curved with bent ends.

Protein Lmo1855, previously designated PBPD3, did not bind any of the antibiotic derivatives tested, similarly to the homologous enterococcal protein VanY.

Conclusions: Nine out of the ten putative L. monocytogenes PBP genes were shown to encode proteins that bind derivatives of $\beta$-lactam antibiotics, thus enabling their positive identification. PBPD2 (Lmo2812) was not visualized in whole cell extracts, most probably due to its low abundance, but it was shown to bind Boc-FL after recombinant overexpression and purification. Mutants lacking Lmo2812 and another low molecular mass (LMM) PBP, PBP5 (PBPD1) - both with DD-carboxypeptidase activity - displayed only slight morphological alterations, demonstrating that they are dispensable for cell survival and probably participate in the latter stages of peptidoglycan synthesis. Since Lmo2812 preferentially degrades low-molecular- mass substrates, this may indicate a role in cell wall turnover.
\end{abstract}

\section{Background}

Penicillin-binding proteins (PBPs) are responsible for the final synthesis steps of the universal peptidoglycan exoskeleton of bacteria. Since their initial identification by Brian Spratt [1] most attention has been paid to the activities of these proteins in model microorganisms such as Escherichia coli, Bacillus subtilis and Streptococcus pneumoniae.

\footnotetext{
* Correspondence: d.korsak@uw.edu.pl

'Institute of Microbiology, University of Warsaw, Miecznikowa 1, 02-096 Warsaw, Poland

Full list of author information is available at the end of the article
}

The rise in resistance to $\beta$-lactam antibiotics and the diversity of the mechanisms involved, including modification of the target PBPs often seen in Gram-positive pathogens, has resulted in increased interest in this group of proteins.

Listeria monocytogenes causes relatively infrequent but often very serious food-borne infections termed listerioses, with mortality rates that can reach $25-30 \%$ [2-4]. Newborns and immunocompromised individuals are at special risk, and in these cases controlling the infection with antimicrobial agents can potentially be hindered
C Biomed Central

C 2010 Korsak et al; licensee BioMed Central Ltd. This is an Open Access article distributed under the terms of the Creative Commons Attribution License (http://creativecommons.org/licenses/by/2.0), which permits unrestricted use, distribution, and reproduction in any medium, provided the original work is properly cited. 
due to the emergence of $L$. monocytogenes isolates with reduced susceptibility to ampicillin $[5,6]$.

The penicillin-binding proteins (PBPs) of L. monocytogenes were first identified by Vicente et al. [7] using radiolabeled $\beta$-lactams, and it was subsequently suggested that PBP3 is the primary lethal target of these antibiotics $[8,9]$. However, as in many other bacteria, the exact mechanism of $\beta$-lactam-induced cell death remains unknown. There have been a limited number of reports dealing with the PBPs of L. monocytogenes. Earlier studies carried out in our laboratory - when only five PBPs were known - resulted in a re-estimation of the copy number of individual $L$. monocytogenes penicillin-binding proteins [10] and elucidation of the enzymatic properties of PBP4 (encoded by lmo2229) and PBP5 (lmo2754) [11-13]. A different approach to studying the penicillin-binding proteins of L. monocytogenes was made possible by the availability of the complete genome sequence of this bacterium [14]. The insertional mutagenesis of genes encoding seven potential PBPs -two of class A, three of the high molecular mass (HMM) class B and two of the low molecular mass (LMM) type - helped to clarify their role [15].

In the present study we have positively identified eight penicillin-binding proteins in whole cell extracts of L. monocytogenes, and another LMM PBP (Lmo2812) was characterized by the Bocillin-FL (Boc-FL)-binding ability of the purified recombinant protein.

\section{Results}

Detection and identification of $L$. monocytogenes PBPs

The "surfaceome" of the model $L$. monocytogenes strain EGDe has been annotated [14] and recently revised [16]. It includes proteins involved in the synthesis of peptidoglycan. Examination of sequence information from a database dedicated to the analysis of the genomes of L. monocytogenes (strain EGDe) and its non-pathogenic relative Listeria innocua (strain CLIP 11262) http:// genolist.pasteur.fr/ListiList, as well as that from the Pfam database http://www.sanger.ac.uk/Software/Pfam and information from the NCBI Conserved Domain database http://www.ncbi.nlm.nih.gov/COG/ and the Interpro database http://www.ebi.ac.uk/interpro/, has identified 10 putative genes for PBPs, classified according to molecular class (Table 1).

PBPs form a covalent complex with $\beta$-lactam antibiotics [1]. When fluorescent $\beta$-lactams are employed, these proteins can be visualized immediately following SDSPAGE [17]. Total protein from whole cells or a cell wall extract of $L$. monocytogenes EGD were incubated with different concentrations of Boc-FL, Bocillin-650 (Boc-650) or Ampicillin-Alexa430 (Amp-430) for $30 \mathrm{~min}$ at $37^{\circ} \mathrm{C}$. The highest affinity binding was obtained with Boc-FL and bands identified using this compound in the whole cell assay are shown in Figure 1. PBPs A1, B2, B1, A2, B3, D1, C1 and C2 were also identified with Boc-650 and Amp-430 (data not shown). Two types of non-specific band were also observed (lane 1, $0 \mu \mathrm{M}$ Boc-FL) and they represent the natural intrinsic fluorescence of other proteins in the cell extract. However, the bands that are absent in lane 8 (ampicillin $100 \mu \mathrm{g} / \mathrm{ml}, 50 \mu \mathrm{M}$ Boc-FL) compared with lane 7 (50 $\mu \mathrm{M}$ Boc-FL) represent specific PBPs. Those bands that completely disappeared (PBPB1, PBPD1), partially disappeared (PBPA1, PBPB2, PBPA2 and PBPB3) or remained present (PBPC1 and PBPC2) reflect total, partial and no binding of ampicillin, respectively. The results of an experiment examining saturation with $50 \mu \mathrm{M}$ Boc-FL, the binding capacity of each PBP for Boc-FL and the affinity of the PBPs for ampicillin (Amp) are presented in Table 2. These assays involved incubation of whole cell with ampicillin followed by a similar incubation with Boc-FL. Therefore, only those PBPs with no or low affinity for ampicillin would be able to bind Boc-FL during the second incubation. The deacylation rate for the PBPs is actually extremely low, which permitted their detection in the gel for several hours after binding. Boc-FL binding to PBPs B1 and D1 was completely inhibited by Amp at $100 \mu \mathrm{g} / \mathrm{ml}$, and these two PBPs exhibited high $(\mathrm{Kd} 50=0.25 \mu \mathrm{M})$ and medium $(\mathrm{Kd} 50=$ $5.0 \mu \mathrm{M}$ ) affinity for Boc-FL, respectively. PBPs A1, B3, C1 and $\mathrm{C} 2$ showed low affinity $(\mathrm{Kd} 50>10 \mu \mathrm{M})$ for Boc-FL.

\section{Characterization of protein Lmo2812 (PBPD2)}

Gene lmo2812 was amplified by PCR from the wild-type EGD strain and cloned in vector pET30a without its putative lipobox signal peptide. Expression of the Histagged fusion protein in E. coli BL21(DE3) cells was induced with IPTG and it was purified from cell lysates on a nickel affinity column. The recombinant Lmo2812 protein was eluted from the column by washes with 250 and $500 \mathrm{mM}$ imidazole. These two fractions were combined and further purified on a desalting column, yielding $4 \mathrm{mg} / \mathrm{ml}$ of pure protein.

The purified protein was incubated with different concentrations of Boc-FL $(0.25,0.5,2.5,5$ and $10 \mu \mathrm{M})$. Saturation binding studies showed that Lmo2812 covalently bound Boc-FL, indicating that the recombinant protein retained its authentic activity. Lmo2812 was the major band on gels, with a slower migrating minor band thought to represent a dimeric form (Figure 2).

The $\beta$-lactam binding capacity of Lmo2812 was evaluated with three different fluorescent antibiotics: Boc-FL, Boc-650 and Amp-430. The purified protein was able to bind these compounds with apparent affinity constants (Kd50) of 2.5, 2.8 and $18.5 \mu \mathrm{M}$, respectively.

Since most LMM PBPs are DD-carboxypeptidases, the enzymatic activity of Lmo2812 was characterized in an in vitro assay using the synthetic tripeptide $\mathrm{N} \alpha$, 
Table 1 The full set of predicted PBPs in L. monocytogenes

\begin{tabular}{|c|c|c|c|c|c|c|c|c|}
\hline $\mathrm{PBP}^{a}$ & $\mathrm{PBP}^{b}$ & gene $^{c}$ & Class $^{d}$ & Prototype & aa & MW (kDa) & IP & Putative domain structure ${ }^{\mathrm{e}}$ \\
\hline PPBA1 & PBP1 & Imo1892 & $\mathrm{A}-3$ & PBP1a (Spn) & 827 & 90.87 & 9.15 & SP- $\Phi$-TG-TP \\
\hline PBPB2 & PBP2 & $\operatorname{lmo2039}$ & B-4 & PBP2x(Spn) & 751 & 81.89 & 7.77 & SP-Ф-D-TP \\
\hline PBPB1 & PBP3 & $\operatorname{lmo1438}$ & B-5 & PBP2b(Spn) & 721 & 79.91 & 8.26 & SP-Ф-D-TP \\
\hline PBPA2 & PBP4 & Imo2229 & $A-4$ & PBP2a(Spn) & 714 & 77.85 & 6.75 & SP-Ф-TG-TP \\
\hline PBPB3 & -二- & Imo0441 & B-1 & PBP2a(Sau) & 678 & 74.60 & 6.57 & SP-Ф-MecAN-D-TP \\
\hline PBPD1 & PBP5 & $1 \mathrm{mo} 2754$ & C-T5 & PBP3(Spn) & 445 & 48.08 & 7.63 & SP-CP-CA \\
\hline PBPC1 & -—— & Imo0540 & $\mathrm{C}-\mathrm{TH}$ & $\mathrm{AmpH}(\mathrm{EcO})$ & 397 & 44.53 & 9.70 & SP-BLA \\
\hline PBPC2 & -—— & Imo1916 & $\mathrm{C}-\mathrm{TH}$ & R61 (SR61) & 335 & 37.84 & 7.04 & BLA \\
\hline PBPD3 & -—— & Imo1855 & M15B & -— & 274 & 31.08 & 5.46 & SP-CP(VanY) \\
\hline PBPD2 & -二- & Imo2812 & C-T5 & PBP5 (Bsu) & 272 & 29.48 & 4.59 & SP(lipo)-CP \\
\hline
\end{tabular}

${ }^{a}$ Nomenclature of PBPs as defined in [16]; ${ }^{b}$ Nomenclature of PBPs as defined in [7,10]; ${ }^{c}$ gene names as identified in Listilist web server http://genolist.pasteur.fr/

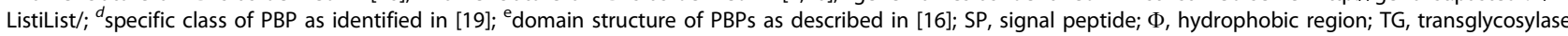
domain; TP, transpeptidase domain; D, interaction domain; MecAN, homologous to PBP2a S. aureus resistance protein; CP, carboxypeptidase domain; CA, Cterminal anchor domain; BLA, $\beta$-lactamase domain; (VanY), homologous to VanY; SP(lipo), lipoprotein signal peptide.

$\mathrm{N} \varepsilon$-Diacetyl-Lys-D-Ala-D-Ala at concentrations of up to $12.5 \mathrm{mM}$ as substrate with $40 \mu \mathrm{g}$ of purified protein. The maximum activity was $0.75 \mathrm{pmoles} / \mu \mathrm{g} \mathrm{min}$, indicating low DD-carboxypeptidase activity under these assay conditions.

No $\beta$-lactamase activity could be detected in assays performed using the purified protein (data not shown).

The hydrolysis of whole peptidoglycan and purified natural muropeptides was also analyzed, but no such enzymatic activity was detected when the purified Lmo2812 (up to $100 \mu \mathrm{g}$ of protein) was incubated for up to $18 \mathrm{~h}$ in the presence of $300 \mu \mathrm{g}$ of whole peptidoglycan or up to $30 \mu \mathrm{g}$ of the natural dimeric muropeptide D45 (NAcGlc-NAcMur-tetrapeptide-NAcGlcNAcMur-pentapeptide). However, Lmo2812 was found to cleave the peptide bond between the subterminal and terminal D-alanine moieties (positions 4 and 5) of the pentapeptide side chain of the monomeric muropepeptide M5 (NAcGlc-NAcMur-pentapeptide) to convert the pentapeptide into a tetrapeptide M4 (NAcGlc-NAcMurtetrapeptide). No such cleavage occurred in the absence of Lmo2812.
The pH-dependence of the activity of Lmo2812 against monomeric muropepeptide M5 was determined in the $\mathrm{pH}$ range of 4.5 to 7.0. The highest activity was detected in assays performed at $\mathrm{pH} 7.0$ in a Tris- $\mathrm{Mg}$ buffer, where half of the substrate was converted to the tetrapeptide (Table 3).

\section{Construction of single and double penicillin-binding protein mutants}

Allelic exchange mutagenesis was used to create in-frame deletions in the $l m o 2812$ and $l m o 2754$ genes, which encode the penicillin-binding proteins Lmo2812 (PBPD2) and PBP5 (PBPD1), respectively. DNA fragments representing regions near the $5^{\prime}$ and $3^{\prime}$ ends of the genes were independently amplified, spliced, and inserted into the E. coli - L. monocytogenes shuttle vector pKSV7 to generate derivatives pKD2812 and pADPBP5, carrying the spliced regions of the $\operatorname{lmo} 2812$ and $l m o 2754$ genes, respectively. $L$. monocytogenes cells transformed with these constructs were grown for several generations in TSBYE broth at $30^{\circ} \mathrm{C}$ in the presence of chloramphenicol to select for chromosomal integration of the plasmids.

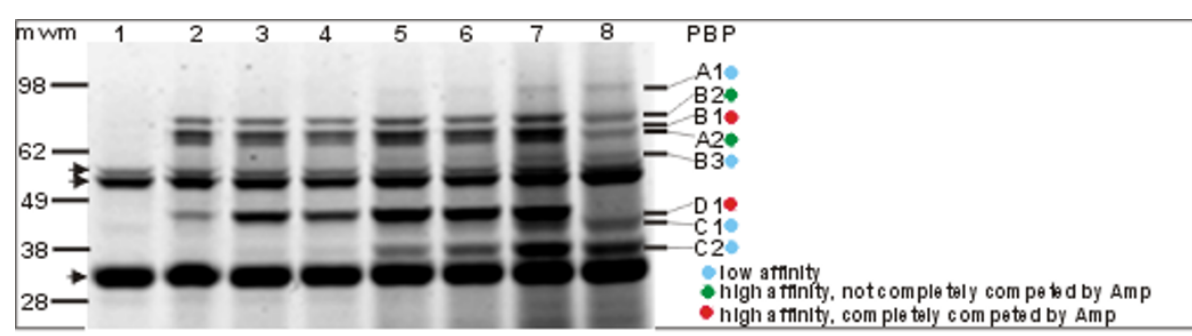

Figure 1 Complete set of PBPs identified with Boc-FL in whole cells of $L$. monocytogenes. Samples of whole cells (100 $\mu \mathrm{g}$ of total protein) were labeled with Boc-FL at concentrations of 0 (1), 0.5 (2), 1 (3), 2.5 (4), 5 (5), 10 (6), $50 \mu \mathrm{M}$ (7) and $50 \mu \mathrm{M}$ plus $100 \mu \mathrm{g} / \mathrm{ml}$ ampicillin (8). Labeled bands were detected directly on the gel, quantified, and their molecular mass estimated. The affinity of each band for Boc-FL (ID50) was estimated from their fluorescence as a function of the concentration of Boc-FL. The name of the PBP corresponding to each band is indicated on the right, while the positions of molecular weight markers (bars) and unspecific bands (arrowheads) are shown on the left. 
Table 2 Competition binding assay and affinity of different PBPs of $L$. monocytogenes for Boc-FL

\begin{tabular}{lcc}
\hline PBP & Boc-FL $\mathbf{K d 5 0} \mathbf{a}^{\mathbf{a}}$ & Ampicillin $^{\mathbf{c}}$ \\
\hline PPBA1 (PBP1) & $>10 \mu \mathrm{M}$ & 95 \\
\hline PBPB2 (PBP2) & $0.25 \mu \mathrm{M}$ & 90 \\
\hline PBPB1 (PBP3) & $0.25 \mu \mathrm{M}$ & 0 \\
\hline PBPA2 (PBP4) & $0.25 \mu \mathrm{M}$ & 90 \\
\hline PBPB3 & $>20 \mu \mathrm{M}$ & 95 \\
\hline PBPD1 (PBP5) & $5.0 \mu \mathrm{M}$ & 0 \\
\hline PBPC1 & $>20 \mu \mathrm{M}$ & 100 \\
\hline PBPC2 & $>20 \mu \mathrm{M}$ & 100 \\
\hline PBPD3 & n.a. & n.a. \\
\hline PBPD2 & $2.5 \mu M^{b}$ & $0^{\text {b }}$ \\
\hline
\end{tabular}

a affinity of the respective bands for Boc-FL estimated from their fluorescence as a function of the concentration of Boc-FL (Kd50)

bobtained with purified recombinant Lmo2812

cpercentage of Boc-FL binding capacity remaining after sample was preincubated with $100 \mu \mathrm{g} / \mathrm{ml}$ ampicillin

Excision of chromosomally-integrated plasmids was facilitated by repeated growth in the absence of antibiotic pressure, and a subsequent shift in the growth temperature was used to cure the cells of the excised plasmids. Colonies grown on TSBYE plates were screened for loss of chloramphenicol resistance and several sensitive clones were then examined by PCR to identify those in which an allelic exchange event had resulted in chromosomal replacement of the wild-type copy of the gene with the mutant allele. This first round of allelic exchange mutagenesis led to the isolation of the derivative $L$. monocytogenes KD2812, which had a 627-bp deletion in the lmo2812 gene.

The KD2812 single mutant was used in a second round of allele replacement mutagenesis, which began with the transformation of this strain with plasmid pADPBP5. Completion of the mutagenesis procedure

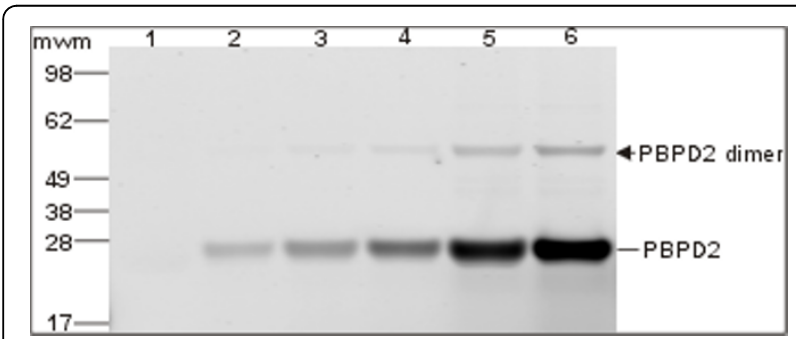

Figure 2 Purified recombinant L. monocytogenes Lmo2812 (PBPD2) identified with Boc-FL. Samples of purified recombinant Lmo2812 $(10 \mu \mathrm{g})$ were labeled with Boc-FL at concentrations of 0 (1), 0.25 (2), 0.5 (3), 2.5 (4), 5 (5) and $10 \mu \mathrm{M}$ (6). Labeled bands were detected directly on the gel, quantified and their molecular mass estimated. The affinity of the bands for Boc-FL (Kd50) was estimated from their fluorescence as a function of the concentration of Boc-FL. The names of the bands are indicated on the right, and the positions of the molecular weight markers are shown on the left.
Table 3 DD-carboxypeptidase activity of recombinant Lmo2812 using M5 muropeptide as the substrate

\begin{tabular}{lcc}
\hline Reaction conditions & M5 (\%) & M4 (\%) \\
\hline Lmo2812, M5, pH 4.5 & 97 & 3 \\
\hline Lmo2812, M5, Tris-Mg, pH 7.0 & 52 & 48 \\
\hline Lmo2812, M5, NaPi, pH 7.0 & 84 & 16 \\
\hline Control, M5, pH 7.0 & 99 & 1
\end{tabular}

apercentage of muropeptides M5 (NAcGlc-NAcMur-pentapeptide) and M4 (NAcGlc-NAcMur-tetrapeptide) determined by HPLC analysis

led to the isolation of a double-mutant strain, L. monocytogenes AD07, which had a 627-bp deletion in the lmo2812 gene and a 1113-bp deletion in the lmo2754 (PBP5) gene.

\section{Characterization of KD2812 and AD07 mutant strains}

To examine the effect of PBP deletion on cell growth rate, the doubling times of cultures of EGD, KD2812 and AD07 were determined. The doubling time of the wild-type strain grown at $37^{\circ} \mathrm{C}$ was $40 \mathrm{~min}$, whereas those of the single and double mutants were 45 and 50 min, respectively. These data indicate that the single and double PBP deletion strains grew significantly slower $(\mathrm{P}<0.05)$ than EGD. The doubling time of the double mutant was also significantly different from that of KD2812. Thus, although the bacteria were viable in the absence of Lmo2812 and PBP5, they grew more slowly than the wild-type.

To determine the effect of these mutations on cell morphology, the strains EGD, KD2812 and DA07 were analyzed by scanning electron microscopy (SEM). As cells of the mutant strains displayed irregular morphology when grown at $42^{\circ} \mathrm{C}$ (Figure $3 ; \mathrm{h}, \mathrm{i}$ ), the cell lengths were only determined when the strains were grown at 30 and $37^{\circ} \mathrm{C}$. Cells of the L. monocytogenes strains lacking Lmo2812 were significantly longer than those of the wild-type (Student's $t$ test, $\mathrm{P}<0.05$ ) (Table 4 ). At $30^{\circ} \mathrm{C}$ the average cell length compared to strain EGD was increased by $38.5 \%$ in strain KD2812 and by $44.8 \%$ in the double mutant strain. The respective values at $37^{\circ} \mathrm{C}$ were $37.5 \%$ and $43 \%$. The populations of the single and double mutant strains also showed some variation in cell morphology. A proportion of the cells of strain KD2812 showed an altered phenotype at each of the tested temperatures. The variant cells were characteristically curved with a bend at either one or both ends and subterminal constrictions. The number of cells with altered morphology was increased as the growth temperature was raised (Figure 3; b, e, h). Cell bending was more pronounced in the population of AD07 mutant cells (Figure 3 ; c, f, i). More than $90 \%$ of cells of the double mutant exhibited irregular morphology at $42^{\circ} \mathrm{C}$. To determine whether disruption of the PBP-encoding 


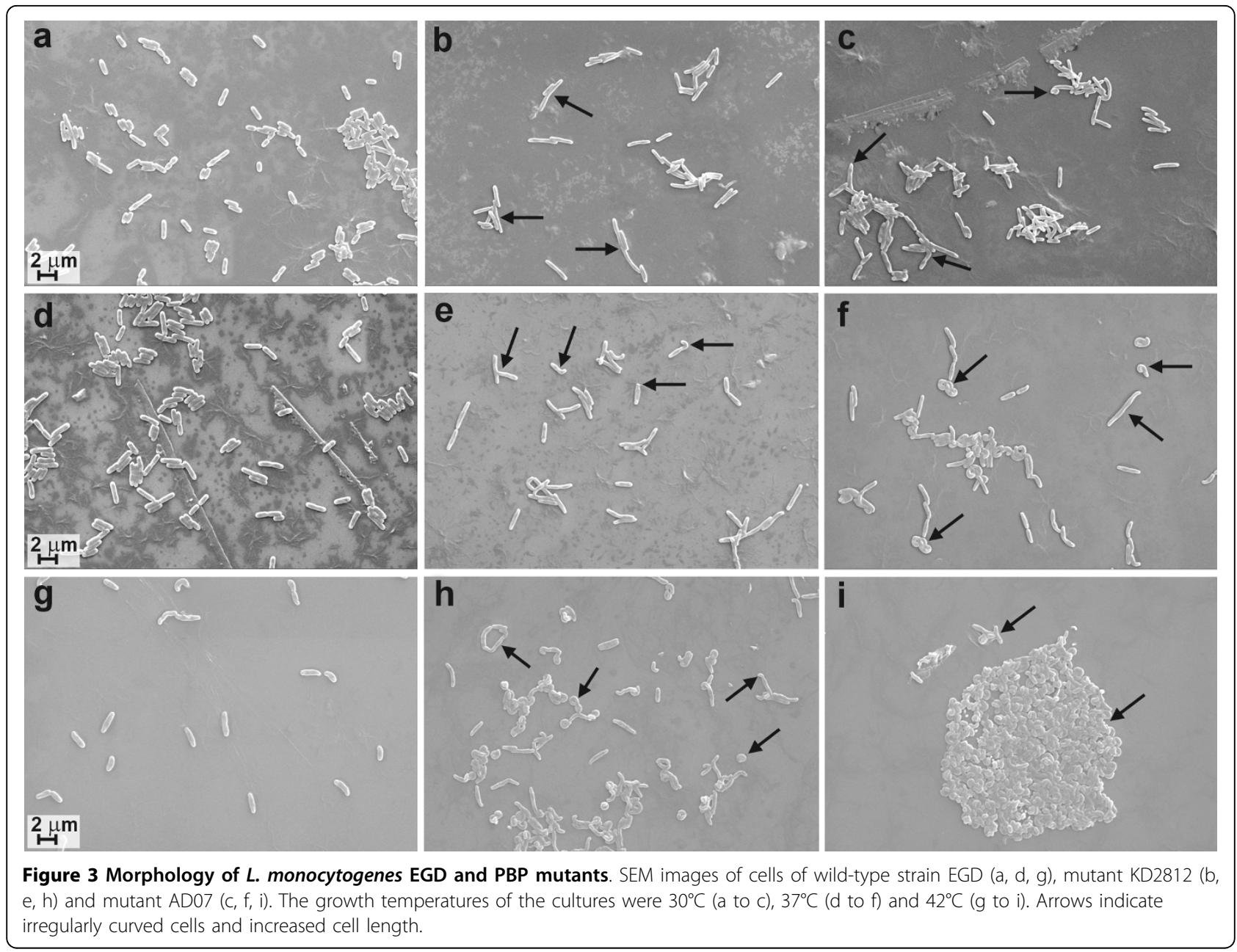

genes had an impact on the $\beta$-lactam resistance of L. monocytogenes, microdilution MIC tests were performed. The results demonstrated that the lack of functional $l m o 2812$ and $l m o 2754$ genes had little effect on the sensitivity of the mutant strains to the panel of $\beta$-lactam antibiotics tested (Table 5). Similar results were found for a mutant of L. monocytogenes lacking PBP5 (PBPD1) examined in a previous study [11].

To compare the murein of L. monocytogenes mutants KD2812 and AD07 with that of the wild-type strain, muropeptides were released from isolated peptidoglycan by complete digestion with muramidase and the reduced muropeptides were analyzed by high performance liquid chromatography (HPLC) to that obtained for wild-type L. monocytogenes, but that of the double mutant was markedly different (Figure 4). Comparison of the peptidoglycan profiles of the wild-type strain and AD07 (Figure 4; $\mathrm{A}$ and $4 \mathrm{C}$ ) indicated that both the composition and relative amount of a number of muropeptides were dramatically altered. All of the well characterized muropeptides identified in the murein of strain EGD, with tripeptide side chains in monomers or cross-linked

Table 4 Cell length of $L$. monocytogenes EGD and mutant strains grown at different temperatures

\begin{tabular}{|c|c|c|c|c|}
\hline Temperature & Strain & Average cell length $(\mu \mathrm{m}) \pm S D$ & Minimum length/Maximum length $(\mu \mathrm{m})$ & $n$ \\
\hline \multirow[t]{3}{*}{$30^{\circ} \mathrm{C}$} & EGD & $1.70 \pm 0.38$ & $0.99 / 3.80$ & 245 \\
\hline & KD2812 & $2.35 \pm 0.76$ & $1.19 / 6.97$ & 124 \\
\hline & AD07 & $2.46 \pm 0.68$ & $1.44 / 6.43$ & 111 \\
\hline \multirow[t]{3}{*}{$37^{\circ} \mathrm{C}$} & EGD & $1.80 \pm 0.44$ & $1.05 / 3.64$ & 150 \\
\hline & KD2812 & $2.48 \pm 0.70$ & $1.43 / 4.70$ & 106 \\
\hline & AD07 & $2.581 \pm 0.6$ & $1.56 / 5.15$ & 50 \\
\hline
\end{tabular}


Table 5 MICs of some $\beta$-lactam antibiotics against $L$. monocytogenes EGD and mutant strains

\begin{tabular}{lccc}
\hline Antimicrobial agent & \multicolumn{3}{c}{ MIC $(\boldsymbol{\mu g} / \mathbf{m l})$} \\
\hline penicillin & EGD & KD2812 & AD07 \\
ampicillin & 0.16 & 0.16 & 0.08 \\
oxacillin & 0.31 & 0.31 & 0.16 \\
piperacillin & 2.5 & 2.5 & 1.25 \\
cefalotin & 1.25 & 1.25 & 1.25 \\
cefoxitin & 2 & 2 & 2 \\
cefotaxim & 32 & 32 & 32 \\
ceftazidime & 6 & 6 & 6 \\
\hline & 256 & 256 & 256 \\
\hline
\end{tabular}

muropeptides (e.g. muropeptides 1, 2, 3, 4, 5), were dramatically decreased or entirely absent in the double mutant. Furthermore, a number of novel muropeptides (B1 to B7) were detected in AD07 pepidoglycan. Peaks $\mathrm{B} 1$ and B2 may correspond to monomers with a disaccharide-pentapeptide structure, while B3-B7 may represent different forms of a dimer - a bis-disaccharide penta-tetra [18].

\section{Discussion}

Previous analyses [7-10] of the L. monocytogenes cell membrane identified only five proteins able to bind $\mathrm{I}^{125}$. penicillinX, $\mathrm{H}^{3}$-benzylpenicillin, $\mathrm{S}^{35}$-penicillin or $\mathrm{I}^{125}$ ampicillin (PBP1, PBP2, PBP3, PBP4, PBP5), which correspond to $\mathrm{PBPA} 1, \mathrm{~B} 2, \mathrm{~B} 1, \mathrm{~A} 2$ and $\mathrm{D} 1$, respectively. In silico analysis of the $L$. monocytogenes genome revealed the presence of ten open reading frames that potentially encode penicillin-binding proteins [16]. We believe that the present study is the first to have used fluorescently labeled antibiotics (Boc-FL, Boc-650 and Amp-430) to identify the PBPs of $L$. monocytogenes. With this method, we were able to identify eight PBPs, both in whole cell and membrane extracts. PBPB3, encoded by the gene $l m o 0441$, was classified as a subclass B1 PBP [19]. All PBPs in this subclass, e.g. PBP2a of Staphylococcus aureus and PBP5 of Enterococcus faecium, are thought to exhibit low affinity for penicillin [20]. We found that PBPB3 also has low affinity for all the $\beta$-lactams tested. A recent study of seven $L$. monocytogenes genes encoding potential penicillin-binding proteins showed that interruption of the 1 mo0441 gene resulted in increased susceptibility of strain EGDe to $\beta$ lactams [15]. It was concluded that protein Lmo0441 (PBPB3) may play a central role in the $\beta$-lactam resistance of L. monocytogenes [15]. We identified two additional LMM PBPs, PBPC1 and PBPC2, which contain a $\beta$-lactamase class $\mathrm{C}$ domain. $\mathrm{PBPC} 1$ is predicted to be located at the surface of the bacterium, while PBPC2 lacks any recognized cell surface association domain [16]. However, we detected both proteins in intact cells, which indicates that some physical interaction of PBPC2 with the cell wall must exist.

The product of gene lmo1855, Lmo1855 (PBPD3), was not found to bind $\beta$-lactams with any of the various methods employed and consequently cannot be considered a PBP.

Lmo2812 (PBPD2), a low molecular mass PBP, has been identified as a class $C$ type 5 protein related to the peptidase S11 family [19]. As Lmo2812 was not observed in Boc-FL-, Boc-650- and Amp-430-labeled extracts, it seemed possible that it does not bind $\beta$-lactam antibiotics. However, $\beta$-lactam binding experiments with purified recombinant protein demonstrated that Lmo2812 does bind the three different fluorescent antibiotics efficiently. The apparent affinity constants (Kd50) for Boc-FL, Boc-650 and Amp-430 were 2.5, 2.8 and $18.5 \mu \mathrm{M}$, respectively. The absence of an observable band corresponding to Lmo2812 following SDS-PAGE of the Boc-FL-labeled listerial extract cannot be due to lack of interaction with the $\beta$-lactam. This result suggests that $L$. monocytogenes grown in culture expresses this protein at a very low level. It has recently been shown that the two-component system CesRK controls the transcriptional induction of $l m o 2812$. The expression of $l m o 2812$ is positively regulated by CesR and inducible with ethanol and cefuroxime [21]. On the other hand, we were able to identify protein Lmo0441 in a whole cell extract using fluorescent-labelled antibiotics, and the expression of this PBP is also dependent on CesR [21].

Bacteria often have a major type-5 PBP which represents the most abundant LMM PBP they produce. The most highly expressed PBP in listerial membranes is PBP5. In a previous study we confirmed that PBP5 is a DD-carboxypeptidase that preferentially degrades lowmolecular-weight substrates [11]. In the present study we found that PBP5 is also a protein with a high affinity for $\beta$-lactams.

L. monocytogenes produces one more type-5 PBP Lmo2812 - but its role in cell wall biosynthesis and catalytic activity had not previously been examined. In this study, recombinant Lmo2812 was expressed in E. coli and purified in order to characterize its enzymatic activity and role in cell physiology. Lmo2812 lacking its signal sequence was expressed as a His-tagged fusion protein in the cytoplasm of $E$. coli, which allowed the purification of large amounts of functionally active protein.

Type-5 PBPs, with the exception of S. aureus PBP4, are strict DD-carboxypeptidases and are unable to catalyze transpeptidation reactions [19]. Using the synthetic tripeptide $\mathrm{N} \alpha, \mathrm{N} \varepsilon$-Diacetyl-Lys-D-Ala-D-Ala and the natural monomer NAcGlc-NAcMur-pentapeptide in an in vitro assay, we showed that Lmo2812 displays weak 

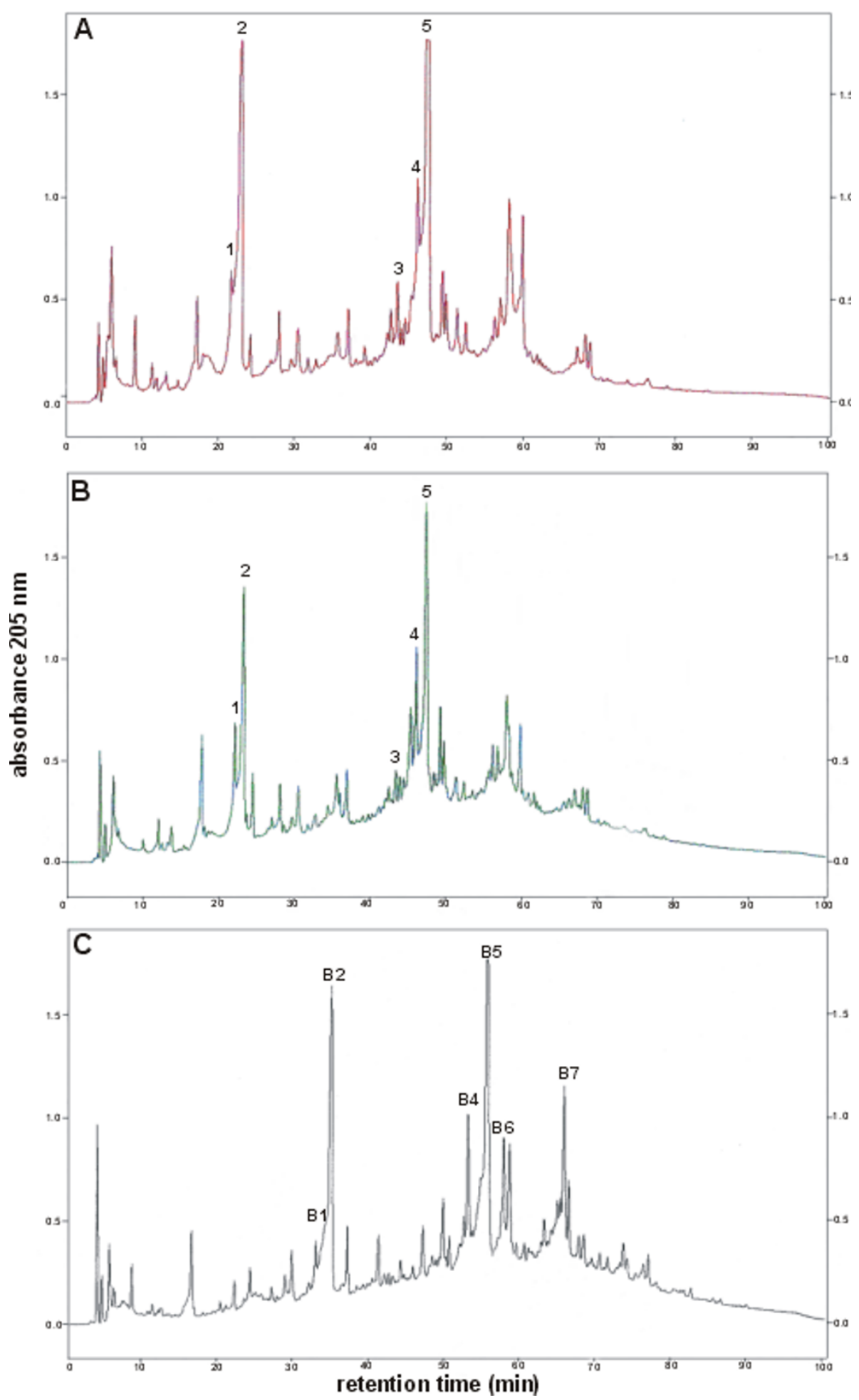

Figure 4 HPLC elution patterns of muropeptides from wild-type and mutant $L$. monocytogenes peptidoglycan. Muropeptides produced by the enzymatic hydrolysis of peptidoglycan purified from wild-type L. monocytogenes EGD (A), mutant KD2812 lacking functional Lmo2812 (B), and mutant AD07 lacking functional Lmo2812 and PBP5 (C), were reduced and separated by reversed phase HPLC and the $A_{205}$ of the eluate was monitored: 1, 2 disaccharide-tripeptide monomers; 3,4,5 bis-disaccharide tri-tetra peptide dimers. 
DD-carboxypeptidase activity, cleaving the peptide bond between the subterminal and terminal D-alanine moieties. However, the recombinant Lmo2812 was active against neither $E$. coli peptidoglycan nor the natural dimeric muropeptide D45 (disaccharide pentapeptide disaccharide tetrapeptide). This suggests that Lmo2812, like PBP5 [11], preferentially degrades low-molecularweight substrates. Analysis of the muropeptide profiles of a L. monocytogenes mutant demonstrated that the lack of Lmo2812 activity does not affect the muropeptide structure of its peptidoglycan. However, the ratio of pentapeptides to tripeptides was found to be increased in cells lacking both Lmo2812 and PBP5. Similar changes have been observed in the peptidoglycan from a L. monocytogenes mutant lacking PBP5 [12], B. subtilis devoid of PBP5 [18] and S. pneumoniae with disrupted PBP3 activity [22]. These changes in the muropeptide profile indicate that L. monocytogenes PBP5, like PBP5 of B. subtilis and PBP3 of S. pneumoniae, is a DD-carboxypeptidase that plays a basic role in the maturation of the cell wall peptidoglycan.

Mutations in genes coding for low molecular mass PBPs are not lethal for the bacterial cell and in general these proteins seem to be redundant. Mutants can survive not only the lack of individual LMM PBPs, e.g. Pseudomonas aeruginosa [23], S. pneumoniae [24], S. aureus [25] and Myxococcus xanthus [26], but also the loss of all LMM PBPs, e.g. E. coli [27], Neisseria gonorrhoeae [28] and B. subtilis [29]. Similarly, we demonstrated that the inactivation of L. monocytogenes genes $l m o 2812$ and $l m o 2754$ is not lethal and these gene products are dispensable for the growth and survival of the cells.

The results of the present and previous studies indicate that the growth of $L$. monocytogenes is only slightly impaired when it lacks the activities of Lmo2812 or both Lmo2812 and PBP5 [11,12]. Reduced growth rates have also been reported for a $S$. pneumoniae mutant lacking functional PBP3 [24] and for a double N. gonorrhoeae mutant lacking both PBP3 and PBP4 [28]. On the other hand, no changes in growth rate were observed for E. coli or B. subtilis mutants lacking most or all of their DD-carboxypeptidase activity [27,29].

However, the loss of Lmo2812 did result in significant changes in morphology. The mutant cells were significantly longer, slightly curved and had bent ends. These changes were even more pronounced in the double mutant AD07 lacking both Lmo2812 and PBP5. This finding is interesting because we did not notice any alterations in cell shape in a L. monocytogenes mutant lacking PBP5 alone, although the cell wall of the mutant was much thicker than that of the parental strain [11,12], even though Guinane et al. [15] did describe such changes. The differences between our observations may be due to variation in the strain (EGD versus EGDe) or growth conditions employed [15].

The reason for the prominent morphological changes in strain KD2812 is difficult to pinpoint since there do not seem to be any remarkable changes in the muropeptide structure of the peptidoglycan of this mutant. However, the observed changes in cell morphology implicate the protein in the late stages of peptidoglycan synthesis, presumably in the determination of the availability of pentapeptide substrates. Our finding that Lmo2812 preferentially degrades low-molecular-weight substrates may point to the a role for this protein in cell wall turnover. Further studies are required to clarify the function of Lmo2812, although, as in the case of extensive studies on the D-alanine carboxypeptidases of E. coli [30] and other bacteria, they may not yield conclusive results.

\section{Conclusions}

The results of this study conclusively show that nine of the ten previously identified putative PBP genes of $L$. monocytogenes code for proteins that bind $\beta$-lactam antibiotics and their labeled or fluorescent derivatives. Eight of these proteins were identified in whole cell extracts, whereas the ninth protein, Lmo2812, was only shown to bind $\beta$-lactams following expression in E. coli and subsequent purification by affinity chromatography. The inability to detect Lmo2812 activity in the L. monocytogenes cell may be explained by the low abundance of this protein, whose expression is regulated by the two-component system CesRK [21]. We have also demonstrated that the LMM PBP Lmo2812 is a DD-carboxypeptidase and has no discernible $\beta$-lactamase activity. Mutants lacking the protein grow normally, although their cells are often longer and slightly curved. Similar morphological changes were observed in the case of a double mutant lacking two LMM carboxypeptidases: Lmo2812 and Lmo2754. Our results indicate that Lmo2812 most probably participates in the late stages of peptidoglycan synthesis, in the determination of the availability of pentapeptide substrates. Moreover, the fact that Lmo2812 preferentially degrades low-molecular-weight substrates may point to a role in cell wall turnover. The product of the tenth putative PBP gene, Lmo1855, was not found to bind $\beta$-lactams with any of the various methods employed and consequently cannot be considered a $\mathrm{PBP}$. In this respect it resembles the homologous protein VanY from VanA- and VanB-type enterococcal strains. This study extends the number of identified penicillin-binding proteins from the original five $[7,10]$ to the final number of nine which represents the full set of these proteins in L. monocytogenes. 


\section{Methods}

Strains, plasmids and growth conditions

E. coli BL21(DE3) and DH5 $\alpha$ were grown aerobically at $37^{\circ} \mathrm{C}$ on Luria-Bertani (LB) medium. L. monocytogenes strains were grown on Tryptic Soy Broth Yeast Extract (TSBYE) and Brain Heart Infusion (BHI) media at $37^{\circ} \mathrm{C}$ unless otherwise stated. Plates of solid LB or TSBYE media were prepared following the addition of agar to $1 \%(\mathrm{w} / \mathrm{v})$. Ampicillin $(100 \mu \mathrm{g} / \mathrm{ml})$ or kanamycin $(30 \mu \mathrm{g} /$ $\mathrm{ml})$ and chloramphenicol $(10 \mu \mathrm{g} / \mathrm{ml})$ were added to broth or agar media as required. When necessary, 0.1 mM IPTG (isopropyl $\beta$-D-1-thiogalactopyranoside) and $\mathrm{X}$-Gal (5-bromo-4-chloro-3-indolyl-b-D-galactopyranoside) $(20 \mu \mathrm{g} / \mathrm{ml})$ were spread on agar plates $30 \mathrm{~min}$ prior to plating. The bacterial strains, plasmids and oligonucleotide primers used in this study are shown in Tables 6 and 7.

\section{Construction of $L$. monocytogenes mutant strains (i) Construction of the $\Delta / m 02812$ single mutant}

The splicing by overlap extension (SOE) PCR approach was used to create an internal deletion construct for the lmo2812 gene. Primers La2812 and Pb2812 (Table 7) were used to amplify a 545-bp fragment comprising the $5^{\prime}$ end of $\operatorname{lmo} 2812$, and primers Lc2812 and Pd2812 were used to amplify a 522-bp fragment comprising the 3 ' end of this gene from genomic DNA L. monocytogenes EGD. The two fragments were purified and used as the templates in a third PCR with primers La2812 and $\operatorname{Pd} 2812$, which generated a $\Delta l m o 2812$ allele with a 627-bp deletion extending from nucleotides +73 to +700 . Deletions in the gene $\operatorname{lmo} 2754$ were constructed by a similar approach using SOE primers shown in Table 7 . The $\Delta l m o 2754$ allele has a 1113 -bp deletion (extending from nucleotides +86 to +1219 ). The $\Delta l m o 2812$ and $\Delta l m o 2754$ alleles were ligated as blunt-
Table 7 Oligonucleotide primers used in this study

\begin{tabular}{ll}
\hline primer & Sequence $\mathbf{5}^{\prime} \rightarrow \mathbf{3}^{\prime}$ \\
\hline pET6up3 $^{\text {a }}$ & AGCAATCATATGGCGGTTATTCAGTCG \\
pET6down & ATGCTCGAGATCTCTTTAAACCCAACCTC \\
La2812 & ATCCGCTATCTGAATCGCCT \\
Pb2812 & TTCAGCTGTTCCAATATTGCTCCGTAGAACAGGCTG \\
LC2812 & TTGGAACAGCTGAACGTGGA \\
Pd2812 & CTAGAGTCAATCCGCAGCCA \\
La2754 & CCGTTATTGACATCTGCTAC \\
Pb2754 & CCGCAGAAGCACCAATAACTGCCAGCGACGTTGAA \\
LC2754 & TTGGTGCTTCTGCGGCTTGT \\
Pd2754 & TAGCAGATGGCATCATCCGG \\
\hline
\end{tabular}

${ }^{a}$ Nucleotide substitutions to create restriction sites are underlined

${ }^{\mathrm{b}}$ Overhangs complementary to SOE primers are underlined

ended fragments to SmaI-digested E. coli-L. monocytogenes shuttle vector pKSV7 [31] and used to transform E. coli DH5 $\alpha$ to generate plasmids pKD2812 and pADPBP5, respectively. pKD2812 was introduced into L. monocytogenes EGD by electroporation [32] and transformants were selected on TSBYE plates containing $10 \mu \mathrm{g} / \mathrm{ml}$ chloramphenicol. The transformants were grown briefly at $30^{\circ} \mathrm{C}$ and then plated on TSBYE plus chloramphenicol and grown at $42^{\circ} \mathrm{C}$ to select for integration of the plasmid by homologous recombination. Colonies with a chromosomal integration were then serially propagated in TSBYE without chloramphenicol at $30^{\circ} \mathrm{C}$. Single clones were picked and replica plated on TSBYE and TSBYE plus chloramphenicol to identify those having undergone excision and loss of the plasmid. The presence of the desired allelic exchange in chloramphenicol-sensitive colonies was then confirmed by PCR using primers La2812 and Pd2812. The resulting mutant strain with a deletion in the 1 mo2812 gene was designated KD2812.

Table 6 Strains and plasmids used in this study

\begin{tabular}{|c|c|c|}
\hline Strain or plasmid & Relevant genotype and features & Reference or source \\
\hline \multicolumn{3}{|c|}{ strains } \\
\hline EGD & L. monocytogenes wild-type & \\
\hline KD2812 & $\Delta / m o 2812$ derivative of $E G D$ & This work \\
\hline AD07 & $\Delta / m o 2754$ derivative of KD2812 & This work \\
\hline E. coli DH5 $\alpha$ & 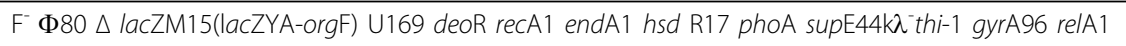 & \\
\hline E. coli BL21(DE3) & $\mathrm{F}^{-}$ompT gal dcm hsdS $\mathrm{S}_{\mathrm{B}}\left(\mathrm{r}_{\mathrm{B}}^{-} \mathrm{m}_{\mathrm{B}}{ }^{-}\right) \lambda(\mathrm{DE} 3)$ & Novagen \\
\hline \multicolumn{3}{|c|}{ plasmids } \\
\hline pET30a & & Novagen \\
\hline pAD3 & pET30a derivative containing Imo2812 gene & This work \\
\hline pKSV7 & temperature-sensitive integration vector; MCS ; lacZ; $\beta$-lac; cat, pE194 Ts rep & [31] \\
\hline pKD2812 & pKSV7 carrying the $\Delta / m o 2812$ allele & This work \\
\hline pADPBP5 & pKSV7 carrying the $\Delta / m o 2754$ allele & This work \\
\hline
\end{tabular}

${ }^{\mathrm{a}} \mathrm{MCS}$ - multiple cloning site 
(ii) Construction of a $\Delta / m o 2812 \Delta / m o 2754$ double mutant A double mutant strain was constructed by introducing the pKSV7 derivative pADPBP5 into L. monocytogenes KD2812 by electroporation. This was followed by the integration excision, curing and screening steps described above. The desired allelic exchange event was confirmed by PCR using the primers La2754 and Pd2754, and a PBP assay. The resulting mutant strain with deletions in the $l m o 2812$ and $l$ mo2754 genes was designated AD07.

\section{Inducible expression of recombinant Lmo2812 protein}

Recombinant expression experiments were performed with $E$. coli BL21(DE3) harboring a derivative of the vector pET30a (Novagen). The lmo2812 gene without its signal sequence was amplified from L. monocytogenes EGD genomic DNA using primers designed from its sequence in GenBank (accession number AL591984). The upstream primer pET6up3 (Table 7) annealed to lmo2812 codons 33-38 and contained an in-frame NdeI restriction site at the $5^{\prime}$-end and a translation initiation codon in frame with the triplet coding for the first residue of the mature Lmo2812, whereas the downstream primer pET6down annealed to the last seven codons of the coding sequence and contained a XhoI site at the 5 '-end. The PCR thermocycle was performed using a gene cycler (Amersham Biotech) and consisted of an initial denaturation for $5 \mathrm{~min}\left(94^{\circ} \mathrm{C}\right)$ followed by 30 cycles of amplification $\left(30 \mathrm{~s}\right.$ at $94^{\circ} \mathrm{C}, 30 \mathrm{~s}$ at $55^{\circ} \mathrm{C}$ and $45 \mathrm{~s}$ at $72^{\circ} \mathrm{C}$ ) and a final extension for $10 \mathrm{~min}$ at $72^{\circ} \mathrm{C}$. The amplified fragment was digested with NdeI and XhoI and cloned into vector pET30a that had been digested with the same endonucleases, which fused lmo2812 with a sequence encoding a hexahistidine peptide. The cloned insert was sequenced and found to be identical to the lmo2812 sequence in the completed EGDe genome (accession number AL591984). The expression plasmid pAD3 (pET30a-lmo2812) was used to transform E. coli BL21(DE3).

\section{Overexpression and purification of a soluble recombinant form of Lmo2812}

For the expression of recombinant Lmo2812 protein, an overnight culture of strain BL21(DE3) harboring the plasmid pAD3 was diluted 1:100 into 1 litre of LB medium and this was incubated with shaking at $37^{\circ} \mathrm{C}$. When the $\mathrm{OD}_{600}$ reached 0.6 , IPTG (isopropyl $\beta$-D-1-thiogalactopyranoside; Sigma, $1 \mathrm{mM}$ ) was added and the culture was shaken at $37^{\circ} \mathrm{C}$ for 24 hours. The culture was cooled on ice and the cells were then harvested by centrifugation $\left(7000 \times g, 15 \mathrm{~min}, 4^{\circ} \mathrm{C}\right)$. All subsequent steps in the purification of the protein were performed at $4^{\circ} \mathrm{C}$. The cell pellet was resuspended in $50 \mathrm{mM}$ sodium phosphate buffer $(\mathrm{NaPi}), \mathrm{pH} 8.0$ containing $0.3 \mathrm{M} \mathrm{NaCl}$ and
$0.1 \%$ Tween-20. After adding DNase $(10 \mu \mathrm{g} / \mathrm{ml})$ and phenylmethanesulfonyl fluoride $(1 \mathrm{mM})$, the cells were broken by sonication (VCX-600 ultrasonicator Sonics and Materials, USA). Cell debris was removed by centrifugation $\left(7000 \times g, 15 \mathrm{~min}, 4^{\circ} \mathrm{C}\right)$. and the cell lysate supernatant containing the fusion protein was applied to a $5 \mathrm{ml}$ nickel column according to the manufacturer's instructions (Qiagen). The column was washed with wash buffer (50 mM NaPi buffer pH 8.0, 0.3 M NaCl, $20 \mathrm{mM}$ imidazole, $10 \%$ glycerol). The bound proteins were then eluted with a $50 \mathrm{mM} 1 \mathrm{M}$ gradient of imidazole in elution buffer $(50 \mathrm{mM} \mathrm{NaPi}$ buffer $\mathrm{pH} 8.0$, $0.3 \mathrm{M} \mathrm{NaCl}$ ) at a flow rate of $40 \mathrm{ml} / \mathrm{h}$. Protein purity was determined by SDS-PAGE. Fractions 9-10 $(2.5 \mathrm{ml}$ each) containing recombinant Lmo2812 were combined and further purified on an Econo-Pac 10 DG (Bio-Rad) desalting column against column running buffer (50 mM NaPi buffer pH 7.0, $50 \mathrm{mM} \mathrm{NaCl}$ ), following the manufacturer's instructions.

\section{Fluorescent antibiotic binding assay}

Total whole cell proteins or purified recombinant protein resuspended in $50 \mathrm{mM} \mathrm{NaPi}$ buffer, pH 7.0 were labeled by incubation at $37^{\circ} \mathrm{C}$ for $30 \mathrm{~min}$ with different concentrations of Boc-FL (Molecular Probes), Boc-650 (Molecular Probes) or Amp-430 (prepared in the laboratory by coupling ampicillin to Alexa-430), and then separated on a $10 \%$ acrylamide, $3.3 \%$ cross-linkage SDSPAGE gel. To avoid degradation of the fluorescent $\beta$-lactam antibiotics by $\beta$-lactamases, samples were incubated at $37^{\circ} \mathrm{C}$ with clavulanic acid at a final concentration of $10 \mu \mathrm{g} / \mathrm{ml}$ or EDTA at a final concentration of $10 \mathrm{mM}$ for $30 \mathrm{~min}$ before labeling, where appropriate. Competition experiments were carried out by preincubation of the samples with ampicillin $(100 \mu \mathrm{g} / \mathrm{ml})$ for $30 \mathrm{~min}$ at $37^{\circ} \mathrm{C}$, before adding the fluorescent antibiotic. The samples were then further incubated for $30 \mathrm{~min}$ at $37^{\circ} \mathrm{C}$. PBPs were visualized directly on the polyacryloamide gel by fluorescence using a Typhoon 9410 imager (Amersham Biosciences) with excitation wavelengths of 588,633 or $457 \mathrm{~nm}$ and emission filters 520BP40, $670 \mathrm{BP} 30$ or $555 \mathrm{BP} 20$ for Boc-FL, Boc-650 and Amp430 , respectively.

Affinity constants for the binding of the labeled $\beta$-lactase to recombinant Lmo2812 were calculated from the results of binding assays using increasing concentrations of protein and/or antibiotic, and from the binding curves, apparent $\mathrm{Kd}$ values were determined as the concentration of antibiotic required for $50 \%$ of maximum binding.

\section{$\beta$-lactamase activity assay}

$\beta$-lactamase activity was determined using the nitrocefin test (Oxoid) and quantified with $0.10 \mathrm{mM}$ nitrocefin in 
$50 \mathrm{mM} \mathrm{NaPi}\left(\mathrm{pH} 7.0,22^{\circ} \mathrm{C}\right)$ by a spectrophotometric method. Nitrocefin $(50 \mu \mathrm{g} / \mathrm{ml})$ and $10 \mu \mathrm{l}$ of extract were incubated for $1 \mathrm{~h}$ in a final volume of $500 \mu \mathrm{l}$ at room temperature in $50 \mathrm{mM} \mathrm{NaPi} \mathrm{pH} 7.0\left(22^{\circ} \mathrm{C}\right)$. The absorbance was measured at $486 \mathrm{~nm}$.

\section{DD-carboxypeptidase activity assay}

A modification of the method of Frere et al. [33] was used for DD-carboxypeptidase activity measurement. A reaction mixture comprised of $15 \mu \mathrm{l}$ of $\mathrm{N \alpha}, \mathrm{N} \varepsilon$-Diacetyl-Lys-D-Ala-D-Ala $(25 \mathrm{mM}), 3 \mu \mathrm{l}$ of buffer $(300 \mathrm{mM}$ Tris- $\mathrm{HCl} \mathrm{pH} 7.5)$ and $12 \mu \mathrm{l}$ of purified recombinant Lmo2812 was prepared, incubated at $37^{\circ} \mathrm{C}$ and samples were taken every $10 \mathrm{~min}$ for $1 \mathrm{~h}$. To these samples, $5 \mu \mathrm{l}$ of $10 \mathrm{mg} / \mathrm{ml}$ (in methanol) o-Dianisidine (SIGMA) and $70 \mu \mathrm{l}$ of enzyme/coenzyme mix (flavinadenine dinucleotide (FAD), Peroxidase and D-Amino acid Oxidase) were added. These mixtures were incubated at $37^{\circ} \mathrm{C}$ for $5 \mathrm{~min}$, then $400 \mu \mathrm{l}$ of methanol-water $(\mathrm{v} / \mathrm{v})$ was added and incubation continued at $37^{\circ} \mathrm{C}$ for another $2 \mathrm{~min}$. The absorbance of each reaction was immediately read at $460 \mathrm{~nm}$. A number of controls were performed: reactions containing only recombinant Lmo2812 fractions, reactions lacking recombinant Lmo2812 to establish the level of natural degradation of the tripeptide for at each sampling point, and standard samples containing known amounts of D-alanine.

\section{Enzymatic activity assay with natural muropeptides}

Whole total peptidoglycan and purified muropeptides were isolated from $E$. coli cells as described previously [34]. A $10 \mu \mathrm{g}$ sample of recombinant Lmo2812 was mixed with $5 \mu \mathrm{g}$ of M5 (NAcGlc-NAcMur-pentapeptide) or D45 (NAcGlc-NAcMur-tetrapeptide-NAcGlcNAcMur-pentapeptide) in a volume of $30 \mu \mathrm{l}$ using three different buffer conditions: $\mathrm{pH} 4.5$ (50 mM NaPi, $1 \%$ methanol, pH 4.5), pH 7.0 (30 mM Tris- $\mathrm{HCl}, 3 \mathrm{mM}$ $\mathrm{MgCl}_{2}, \mathrm{pH} 7.0$ ), or $\mathrm{NaPi}$ (50 mM sodium phosphate buffer, pH 7.0). These mixtures were incubated at $37^{\circ} \mathrm{C}$ for 120 min. Control samples of M5 or D45 without Lmo2812 were similarly incubated in $30 \mathrm{mM}$ Tris- $\mathrm{HCl}$ buffer, $3 \mathrm{mM} \mathrm{MgCl}_{2}, \mathrm{pH}$ 7.0. The samples were analyzed by HPLC using a C18 reversed phase column and a methanol gradient to separate the peaks.

\section{Preparation of $L$. monocytogenes cell wall peptidoglycan}

An overnight culture of the required strain $(200 \mathrm{ml})$ was cooled on ice and the cells harvested by centrifugation $\left(7000 \times g, 10 \mathrm{~min}, 4^{\circ} \mathrm{C}\right)$. The cell pellet was resuspended in 1/40th of the original culture volume of $50 \mathrm{mM}$ Tris$\mathrm{HCl}$ buffer, $\mathrm{pH}$ 7.5. Glass beads (diameter 150-215 $\mu \mathrm{m}$; Sigma) were added to the cell suspension $(1 \mathrm{~g}$ per $\mathrm{ml})$ prior to sonication using a VCX-600 ultrasonicator (Sonics and Materials, USA) for ten 1 min bursts at an amplitude of $20 \%$. Unbroken cells were pelleted by centrifugation $\left(7000 \times g, 10 \mathrm{~min}, 4^{\circ} \mathrm{C}\right)$ and the supernatant was collected and mixed with an equal volume of hot $8 \%(\mathrm{v} / \mathrm{v})$ sodium dodecyl sulfate (SDS). This mixture was boiled for $30 \mathrm{~min}$ and the resulting insoluble cell wall preparation was collected by centrifugation $\left(150,000 \times g, 30 \mathrm{~min}, 22^{\circ} \mathrm{C}\right)$ and washed with hot distilled water $\left(60^{\circ} \mathrm{C}\right)$ at least five times to remove SDS. The SDS-free material was treated with $\alpha$-amylase (100 $\mu \mathrm{g} / \mathrm{ml})$ for $2 \mathrm{~h}$ at $37^{\circ} \mathrm{C}$, after which pronase $\mathrm{E}(200 \mu \mathrm{g} /$ $\mathrm{ml}$ ) was added and the incubation continued for $90 \mathrm{~min}$ at $60^{\circ} \mathrm{C}$. Trichloroacetic acid was then added to a final concentration of $5 \%$ and the cell wall suspension was incubated for $24 \mathrm{~h}$ with stirring at $4^{\circ} \mathrm{C}$ to remove teichoic acid. The remaining insoluble material was collected by centrifugation $\left(150,000 \times g, 30 \mathrm{~min}, 4^{\circ} \mathrm{C}\right)$ and washed with cold distilled water until the $\mathrm{pH}$ became neutral. $N$-acetylation of murein was performed using acetic anhydride in the presence of $\mathrm{NaHCO}_{3}$ according to the method of Hayashi et al. [35]. The prepared peptidoglycan was stored at $-20^{\circ} \mathrm{C}$.

\section{Enzymatic hydrolysis of peptidoglycan and HPLC separation of soluble muropeptides}

Prepared L. monocytogenes peptidoglycan samples $(300 \mu \mathrm{g})$ were digested with the muramidase Cellosyl (Hoechst AG) as previously described [12]. Soluble muropeptides were reduced by treatment with sodium borohydride. The reaction was stopped after $30 \mathrm{~min}$ by lowering the $\mathrm{pH}$ to 3.5 with phosphoric acid. The reduced muropeptides were analyzed by HPLC on a Hypersil octadecylsilane (ODS) reversed-phase column $(250 \mathrm{~mm} \times 4 \mathrm{~mm}$, particle size $3 \mathrm{~mm}$ diameter; Teknochroma) according to the method of Glauner [34]. The elution buffers used were $50 \mathrm{mM}$ sodium phosphate containing $0.8 \mathrm{~g} / \mathrm{l}$ sodium azide, $\mathrm{pH} 4.35$ (buffer A) and $15 \%$ methanol in $75 \mathrm{mM}$ sodium phosphate, $\mathrm{pH} 4.95$ (buffer B). Elution conditions were $7 \mathrm{~min}$ isocratic elution in buffer A, 115 min of linear gradient to $100 \%$ buffer $\mathrm{B}$ and $28 \mathrm{~min}$ of isocratic elution in buffer $\mathrm{B}$. The flow rate was $0.5 \mathrm{ml} / \mathrm{min}$ and the column temperature was $35^{\circ} \mathrm{C}$. Eluted compounds were detected by monitoring the $\mathrm{A}_{205}$.

\section{Scanning electron microscopy}

Small cultures (10 ml) of L. monocytogenes EGD, KD2812 and $\mathrm{AD} 07$ were grown at 30,37 or $42^{\circ} \mathrm{C}$ in $\mathrm{BHI}$ medium to an $\mathrm{OD}_{600}$ of 0.6 and then harvested by centrifugation at $(7000 \times g, 10 \mathrm{~min}$, at room temeprature). The cells were fixed for $30 \mathrm{~min}$ in $4 \%$ paraformaldehyde, washed three times in phosphate-buffered saline, $\mathrm{pH} 7.4$, then dehydrated using a graded ethanol series $(25,50,75,96 \%$ ethanol; 15 min for each step). One drop of cell suspension was spread on a microcover, coated with gold, and 
examined using a LEO 1430VP scanning electron microscope (SEM).

\section{Antibiotic susceptibility tests}

Microdilution tests were performed using cationadjusted Mueller-Hinton broth (CAMHB) supplemented with $5 \%$ lysed horse blood containing two-fold dilutions of the antimicrobial agents. These mixtures were dispensed in $100 \mu \mathrm{l}$ aliquots into plastic 96-well plates. To prepare inocula, a single colony of each strain from a TSBYE plate was transferred into $10 \mathrm{ml}$ of the same medium and incubated for $24 \mathrm{~h}$ at $37^{\circ} \mathrm{C}$. These cultures were serially diluted in CAMHB to a concentration of $10^{5} \mathrm{cfu} / \mathrm{ml}$ and $100 \mu \mathrm{l}$ aliquots were added to the microdilution plates. The plates were incubated for $18-20 \mathrm{~h}$ at $37^{\circ} \mathrm{C}$ before the reading of the MIC endpoints. The MIC was the lowest antibiotic concentration at which visible growth was inhibited.

\section{Acknowledgements}

The institutional help of the Areces Foundation to CBMSO is acknowledged. Work in JAA's lab was supported by grants BFU2006-04574 from the Spanish Ministry of Science and Innovation and HEALTH-F3-2009-223431 from the European Community.

\section{Author details}

${ }^{1}$ Institute of Microbiology, University of Warsaw, Miecznikowa 1, 02-096 Warsaw, Poland. 'Facultad de Farmacia y Bioquimica, Universidad de Buenos Aires, Argentina. ${ }^{3}$ Centro de Biologia Molecular "Severo Ochoa", Consejo Superior de Investigaciones Científicas, CSIC-UAM, C/Nicolás Cabrera 1, 28049, Madrid, Spain.

\section{Authors' contributions}

DK carried out the molecular cloning, recombinant protein expression and protein purification as well as the physiological characterization of the obtained mutants, and helped to draft the manuscript. ZM conceived part of the study, participated in its design and coordinated the preparation of the manuscript. GOG conceived part of the study and collaborated in preparation of the manuscript. JAA carried out the purification of natural muropeptides, binding assays in whole cells, purified recombinant proteins and performed enzymatic assays with natural and synthetic substrates. He also participated in the design of the experiments and the preparation of the manuscript. All authors read and approved the final version of manuscript.

Received: 30 March 2010 Accepted: 15 September 2010 Published: 15 September 2010

\section{References}

1. Spratt BG: Distinct penicillin binding proteins involved in the division, elongation, and shape of Escherichia coli K12. Proc Natl Acad Sci USA 1975, 72:2999-3003.

2. McLaughlin J: Listeriosis and L. monocytogenes. Env Policy Practice 1993, 3:201-214.

3. Southwick FH, Purich DL: Intracellular pathogenesis of listeriosis. New Eng J Med 1996, 334:770-776.

4. Hof H: An update on the medical management of listeriosis. Expert Opin Pharmacother 2004, 8:1727-1735.

5. Conter M, Paludi D, Zanardi E, Ghidini S, Vergara A, lanieri A: Characterization of antimicrobial resistance of foodborne Listeria monocytogenes. Int J Food Microbiol 2009, 128:497-500.

6. Harakeh S, Saleh I, Zouhairi O, Baydoun E, Barbour E, Alwan N: Antimicrobial resistance of Listeria monocytogenes isolated from dairybased food products. Sci Total Environ 2009, 407:4022-4027.
7. Vicente MF, Berenguer J, de Pedro MA, Pérez-Diaz JC, Baquero F: Penicillin binding proteins in Listeria monocytogenes. Acta Microbiol Hung 1990, 37:227-231.

8. Gutkind GO, Ogueta SB, de Urtiaga AC, Mollerach ME, de Torres RA: Participation of PBP 3 in the acquisition of dicloxacillin resistance in Listeria monocytogenes. J Antimicrob Chemother 1990, 25:751-758.

9. Pierre J, Boisivon A, Gutmann L: Alteration of PBP 3 entails resistance to imipenem in Listeria monocytogenes. Antimicrob Agents Chemother 1990, 34:1695-1698.

10. Korsak D, Zawadzka J, Siwińska ME, Markiewicz Z: Penicillin-binding proteins of Listeria monocytogenes - a re-evaluation. Acta Microbiol Pol 2002, 51:5-12

11. Korsak D, Vollmer W, Markiewicz Z: Listeria monocytogenes EGD lacking penicillin-binding protein 5 (PBP5) produces a thicker cell wall. FEMS Microbiol Lett 2005, 251:281-288.

12. Korsak D, Popowska M, Markiewicz Z: Analysis of the murein of a Listeria monocytogenes EGD mutant lacking functional penicillin binding protein 5 (PBP5). Pol J Microbiol 2005, 54:339-342.

13. Zawadzka-Skomial J, Markiewicz Z, Nguyen-Distèche M, Devreese B, Frère JM, Terrak M: Characterization of the bifunctional glycosyltransferase/acyltransferase penicillin-binding protein 4 of Listeria monocytogenes. J Bacteriol 2006, 188:1875-1881.

14. Glaser P, Frangeul L, Buchrieser C, Rusniok C, Amend A, Baquero F, Berche P, Bloecker H, Brandt P, Chakraborty T, Charbit A, Chetouani F, Couvé $E$, de Daruvar A, Dehoux $P$, Domann E, Domínguez-Bernal G, Duchaud E, Durant L, Dussurget O, Entian KD, Fsihi H, García-del Portillo F, Garrido P, Gautier L, Goebel W, Gómez-López N, Hain T, Hauf J, Jackson D, Jones LM, Kaerst U, Kreft J, Kuhn M, Kunst F, Kurapkat G, Madueno E, Maitournam A, Vicente JM, Ng E, Nedjari H, Nordsiek G, Novella S, de Pablos B, Pérez-Diaz JC, Purcell R, Remmel B, Rose M, Schlueter T, Simoes N, Tierrez A, Vázquez-Boland JA, Voss H, Wehland J, Cossart P: Comparative genomics of Listeria species. Science 2001, 294:849-852.

15. Guinane $C M$, Cotter PD, Ross PR, Hill C: Contribution of penicillin-binding protein homologs to antibiotic resistance, cell morphology, and virulence of Listeria monocytogenes EGDe. Antimicrob Agents Chemother 2006, 50:2824-2828.

16. Bierne $H$, Cossart P: Listeria monocytogenes surface proteins: from genome predictions to function. Microbiol Mol Biol Rev 2007, 71:377-397.

17. Zhao G, Meier TI, Kahl SD, Gee KR, Blaszczak LC: BOCILLIN FL, a sensitive and commercially available reagent for detection of penicillin-binding proteins. Antimicrob Agents Chemother 1999, 43:1124-1128.

18. Atrih A, Bacher G, Allmaier G, Williamson MP, Foster SJ: Analysis of peptidoglycan structure from vegetative cells of Bacillus subtilis 168 and role of PBP5 in peptidoglycan maturation. J Bacteriol 1999, 181:3956-3966.

19. Sauvage E, Kerff F, Terrak M, Ayala JA, Charlier P: The penicillin-binding proteins: structure and role in peptidoglycan biosynthesis. FEMS Microbiol Rev 2008, 32:234-258.

20. Zapun A, Contreras-Martel C, Vernet T: Penicillin-binding proteins and $\beta$-lactam resistance. FEMS Microbiol Rev 2008, 32:361-385.

21. Gottschalk S, Bygebjerg-Hove I, Bonde M, Nielsen PK, Nguyen TH, Gravesen A, Birgitte Kallipolitis H: The two-component system CesRK controls the transcriptional induction of cell envelope-related genes in Listeria monocytogenes in response to cell wall-acting antibiotics. J Bacteriol 2008, 190:4772-4776.

22. Severin A, Schuster C, Hakenbeck R, Tomasz A: Altered murein composition in a DD-carboxypeptidase mutant of Streptococcus pneumoniae. J Bacteriol 1992, 174:5152-5155.

23. Song J, Xie G, Elf PK, Young KD, Jensen RA: Comparative analysis of Pseudomonas aeruginosa penicillin-binding protein 7 in the context of its membership in the family of low-molecular-mass PBPs. Microbiology 1998, 144:975-983.

24. Schuster CB, Dobrinski B, Hakenbeck R: Unusual septum formation in Streptococcus pneumoniae mutants with an alteration in the $D$, D-carboxypeptidase penicillin-binding proteins 3. J Bacteriol 1990, 172:6499-6505.

25. Kozarich JW, Strominger JL: A membrane enzyme from Staphylococcus aureus which catalyzes transpeptidase, carboxypeptidase, and penicillinase activities. J Biol Chem 1978, 253:1272-1278.

26. Kimura Y, Takashima Y, Tokumasu Y, Sato M: Molecular cloning, sequence analysis, and characterization of a penicillin-resistant DDcarboxypeptidase of Myxococcus xanthus. J Bacteriol 1999, 181:4696-4699. 
27. Denome SA, Elf PK, Henderson TA, Nelson DE, Kevin D, Young KD: Escherichia coli mutants lacking all possible combinations of eight penicillin binding proteins: viability, characteristics, and implications for peptidoglycan synthesis. J Bacteriol 1999, 181:3981-3999.

28. Stefanova ME, Tomberg J, Olesky M, Höltje JV, Gutheil WG, Nicholas RA: Neisseria gonorrhoeae penicillin-binding protein 3 exhibits exceptionally high carboxypeptidase and beta-lactam binding activities. Biochemistry 2003, 42:14614-14625.

29. Popham DL, Gilmore ME, Setlow P: Roles of low-molecular-weight penicillin-binding proteins in Bacillus subtilis spore peptidoglycan synthesis and spore properties. J Bacteriol 1999, 181:126-132.

30. Ghosh AS, Chowdhury C, Nelson DE: Physiological functions of D-alanine carboxypeptidases in Escherichia coli. Trends Microbiol 2008, 16:309-317.

31. Camilli A, Tilney LG, Portnoy DA: Dual roles of plcA in Listeria monocytogenes pathogenesis. Mol Microbiol 1993, 8:143-157.

32. Park SF, Stewart GSAB: High-efficiency transformation of Listeria monocytogenes by electroporation of penicillin-treated cells. Gene 1990, 94:129-132.

33. Frere JM, Leyh-Bouille M, Ghuysen JM, Nieto M, Perkins HR: Exocellular DD-carboxypeptidases- transpeptidases from Streptomyces. Methods Enzymol 1976, 45:610-636.

34. Glauner B: Separation and performance liquid chromatography. Anal Biochem 1988, 172:451-464

35. Hayashi $H$, Araki $Y$, Ito E: Occurrence of glucosamine residues with free amino groups on cell wall peptidoglycan from Bacillus as a factor responsible for resistance to lysozyme. J Bacteriol 1973, 113:592-598.

doi:10.1186/1471-2180-10-239

Cite this article as: Korsak et al:: Identification of the full set of Listeria monocytogenes penicillin-binding proteins and characterization of PBPD2 (Lmo2812). BMC Microbiology 2010 10:239.

\section{Submit your next manuscript to BioMed Central and take full advantage of:}

- Convenient online submission

- Thorough peer review

- No space constraints or color figure charges

- Immediate publication on acceptance

- Inclusion in PubMed, CAS, Scopus and Google Scholar

- Research which is freely available for redistribution

Submit your manuscript at www.biomedcentral.com/submit
C Biomed Central 